\title{
A Review of Aircraft-Subsistence Harvester Conflict in Arctic Alaska
}

\author{
Taylor R. Stinchcomb, ${ }^{1,2}$ Todd J. Brinkman ${ }^{1}$ and Stacey A. Fritz ${ }^{3}$
}

(Received 18 January 2018; accepted in revised form 13 November 2018)

\begin{abstract}
The traditional harvest of wild resources carries significant nutritional, economic, and sociocultural values for rural residents in the Arctic, especially for Indigenous subsistence communities. Rural communities in the Alaskan Arctic have expressed concern that aircraft activity from industry, commercial hunting, research, and tourism disrupts their harvest of wildlife, particularly caribou (Rangifer tarandus). However, little research exists on how aircraft impact harvest opportunities. Our objective was to assess the extent of scientific knowledge on aircraft-harvester interaction in the Arctic through a systematic search of the available literature. We found that no peer-reviewed publications addressed the conflict between aircraft and harvesters in the region. Some literature addressed aircraft impacts to subsistence species, but did not discuss how those impacts would affect local harvesters. Most research has been directed towards studying aircraft impacts on wildlife or humans in urbanized areas rather than in rural, subsistence communities. Therefore, we expanded our review to draw from gray literature (e.g., public records, government documents) to synthesize the current state of concern and perceptions on aircraft disturbance to subsistence harvesters. Based on the gray literature, we found that harvester frustrations were primarily directed toward low-flying aircraft and non-local operations. However, an absence of quantitative information on the extent of interaction between aircraft activity and harvesters hinders an objective assessment of the conflict. Mitigating conflict will require research focused on this data gap and may begin with better cooperation among rural communities, aircraft users, and decision-makers.
\end{abstract}

Key words: aircraft; Alaska; caribou; conflict; human dimensions; subsistence

RÉSUMÉ. La récolte traditionnelle des ressources sauvages comporte d'importantes valeurs nutritionnelles, économiques et socioculturelles pour les résidents des milieux ruraux de l'Arctique, surtout pour les collectivités autochtones axées sur les récoltes de subsistance. Les collectivités rurales de l'Arctique alaskien s'inquiètent du fait que l'activité aérienne à caractère industriel, la chasse commerciale, la recherche et le tourisme perturbent la récolte de la faune, plus particulièrement le caribou (Rangifer tarandus). Cependant, peu de recherches ont été effectuées au sujet des incidences des aéronefs sur les possibilités de récoltes. Notre objectif consistait à évaluer l'étendue des connaissances scientifiques sur l'interaction entre les aéronefs et les récolteurs de l'Arctique en faisant le dépouillement systématique de la documentation disponible. Cela nous a permis de constater qu'il n'existe pas de publications révisées par des pairs au sujet du conflit entre les aéronefs et les récolteurs de la région. Certains documents abordaient les incidences des aéronefs sur les espèces de subsistance, mais ne déterminaient pas les effets de ces incidences sur les récolteurs de la région. La plupart des études portaient sur les incidences des aéronefs sur la faune ou les humains des secteurs urbains plutôt que des collectivités rurales de subsistance. Par conséquent, nous avons poussé notre dépouillement plus loin au point d'inclure la documentation parallèle (comme les dossiers publics, les documents gouvernementaux) afin de faire la synthèse de l'état actuel des préoccupations et des perceptions sur la perturbation causée par les aéronefs à l'égard des récolteurs de subsistance. La documentation parallèle nous a permis de découvrir que les frustrations des récolteurs concernaient principalement les aéronefs volant à basse altitude et les opérations qui ne sont pas locales. Toutefois, l'absence d'information quantitative sur l'étendue de l'interaction entre l'activité aérienne et les récolteurs nuit à l'évaluation objective du conflit. Pour atténuer ce conflit, il faudra faire des recherches visant à combler ce manque de données. Cela pourrait commencer par une meilleure coopération entre les collectivités rurales, les utilisateurs d'aéronefs et les preneurs de décisions.

Mots clés : aéronef; Alaska; caribou; conflit; dimensions humaines; subsistance

Traduit pour la revue Arctic par Nicole Giguère.

\footnotetext{
${ }^{1}$ Institute of Arctic Biology, University of Alaska Fairbanks, 902 N. Koyukuk Dr., PO Box 757000, Fairbanks, Alaska 99775, USA

${ }^{2}$ Corresponding author: trstinchcomb@alaska.edu

${ }^{3}$ Bureau of Land Management, Arctic District Office, 222 University Ave., Fairbanks, Alaska 99709, USA

(C) The Arctic Institute of North America
} 


\section{INTRODUCTION}

Low-flying aircraft traffic is a pressing concern for rural communities across Arctic Alaska. Community members contend that aircraft disturb wildlife and their traditional harvest experience and success (BLM SAP, 2010, 2012-14, 2016; Stephen R. Braund \& Associates, 2013-17; ICAS, 2014; NPR-A Working Group, 2014; NSB, 2016). The traditional harvest of wildlife provides rural Arctic communities with direct nutritional and economic benefits (Nuttall, 2000) and, for Alaska Native communities, underpins social relationships, networks of sharing, and cultural identity (Fall, 2016; BurnSilver et al., 2017). Disruption of harvest practices could therefore undermine the wellbeing and sociocultural integrity of many rural Arctic communities (Lambden et al., 2007; Smith et al., 2009; Loring and Gerlach, 2015). We conducted a systematic review of aircraft disturbance in the Arctic to provide a synthesis of current knowledge and concerns related to this important topic.

Aircraft disturbance is not a recent issue for rural Alaska communities. The conflict between subsistence harvesters and aircraft has been documented for decades in public hearings on proposed industrial developments (U.S. Army Engineer District, Alaska, 1996; BLM, 1997, 2003) and proceedings of the Bureau of Land Management National Petroleum Reserve in Alaska Subsistence Advisory Panel (Stephen R. Braund \& Associates, 2009; BLM SAP, 2010, $2012-14,2016)$. Since 1979, community ethnographies have considered aircraft among external forces that alter local environments and interrupt traditional lifestyles of rural communities (Brown, 1979). Specific reports or observations about aircraft activity harassing wildlife, changing caribou (Rangifer tarandus) migration routes, and frustrating harvesters have been increasing since the early 2000s (Brower and Hepa, 1998; Stephen R. Braund \& Associates, 2009).

Aircraft can affect harvest opportunities by spooking caribou or diverting harvesters away from traditional harvesting areas (BLM SAP, 2010, 2014, 2016; NSB, 2016; Stephen R. Braund \& Associates, 2016). High-traffic areas can also reduce the quality of a harvest experience in that patch of landscape (Heberlein, 2002; Vaske and Shelby, 2008; BLM, 2014; BLM SAP, 2014). Although recent survey estimates show that caribou harvest rates have remained relatively stable for several Arctic Alaska communities (Bacon et al., 2011; Braem et al., 2011; Brown et al., 2016; Stephen R. Braund \& Associates, 2017), traditional knowledge and public testimony suggest that harvesters are responding to aircraft activity in ways that could compromise their harvest success (ICAS, 2014; NPR-A Working Group, 2014; NSB, 2015, 2016). Many harvesters no longer use areas where industrial traffic, including aircraft, is concentrated (Galginaitis and Petterson, 1990; Kunaknana, 2016; Stephen R. Braund \& Associates, 2016). Such avoidance can undermine harvest opportunities by increasing the number and length of trips needed for a successful harvest. These factors increase the economic costs (e.g., fuel) and time associated with traditional harvesting, which can be major challenges to rural Alaska residents with limited employment opportunities (Brinkman et al., 2014).

Avoidance of traditional harvest areas also carries a risk of cultural loss for Alaska Native communities. As harvesters abandon traditional areas, they not only lose those harvest opportunities, but they lose a central piece of their cultural identity (Galginaitis and Petterson, 1990; Nuttall et al., 2005; Cuomo et al., 2008; Ahtuangaruak, 2015; BLM, 2016). The place names and the oral history behind them are no longer passed on to the next generation (BLM, 2003). Such threat of cultural loss contributes to perceptions of aircraft as invasive to the traditional way of life (Cuomo et al., 2008).

Despite the concern and consequences associated with aircraft-harvester interactions in Arctic Alaska, the issue remains difficult to address using contemporary management and monitoring programs (BLM, 2017). Very few efforts have sought to assess the cumulative effects of aircraft activity on subsistence systems and the consequent implications for rural community wellbeing and resilience. Meanwhile, aircraft traffic continues to increase over Arctic Alaska to support transit of Arctic residents, oil and gas development, scientific research, tourism, and commercial hunting opportunities (Carr et al., 2013; Osipov et al., 2016). Acknowledging the importance of this contentious issue in the Arctic, the North Slope Science Initiative created a working group to focus on aircraft disturbance (NSSI, 2017). To address this understudied and important topic, we conduct a systematic search of both the peer-reviewed and gray literature on aircraft disturbance to synthesize the extent of scientific knowledge and perceptions on aircraft disturbance in the Arctic and its distribution by academic discipline. Categorizing by discipline provides information on the extent of research allocated to the human and natural components of this social-ecological system. Our review advances understanding of the complexities of this issue and offers insight on opportunities for researching and managing aircraft impacts on traditional harvest practices.

\section{METHODS}

\section{Study Area}

Our assessment of the interactions between aircraft traffic and traditional harvest opportunities focused on the Arctic Alaska ecoregion, including the North Slope Borough (NSB), the Northwest Arctic Borough (NWAB), and part of the Yukon-Koyukuk Census Area above the Yukon River (Fig. 1). We also include the Nome Census Area (Seward Peninsula) because of its classification as subarctic tundra (Nowacki et al., 2001). Flat tundra covered by sedges, low-lying shrubs, and lichens provides habitat for wide-ranging avian species (e.g., Branta bernicla, Anser 


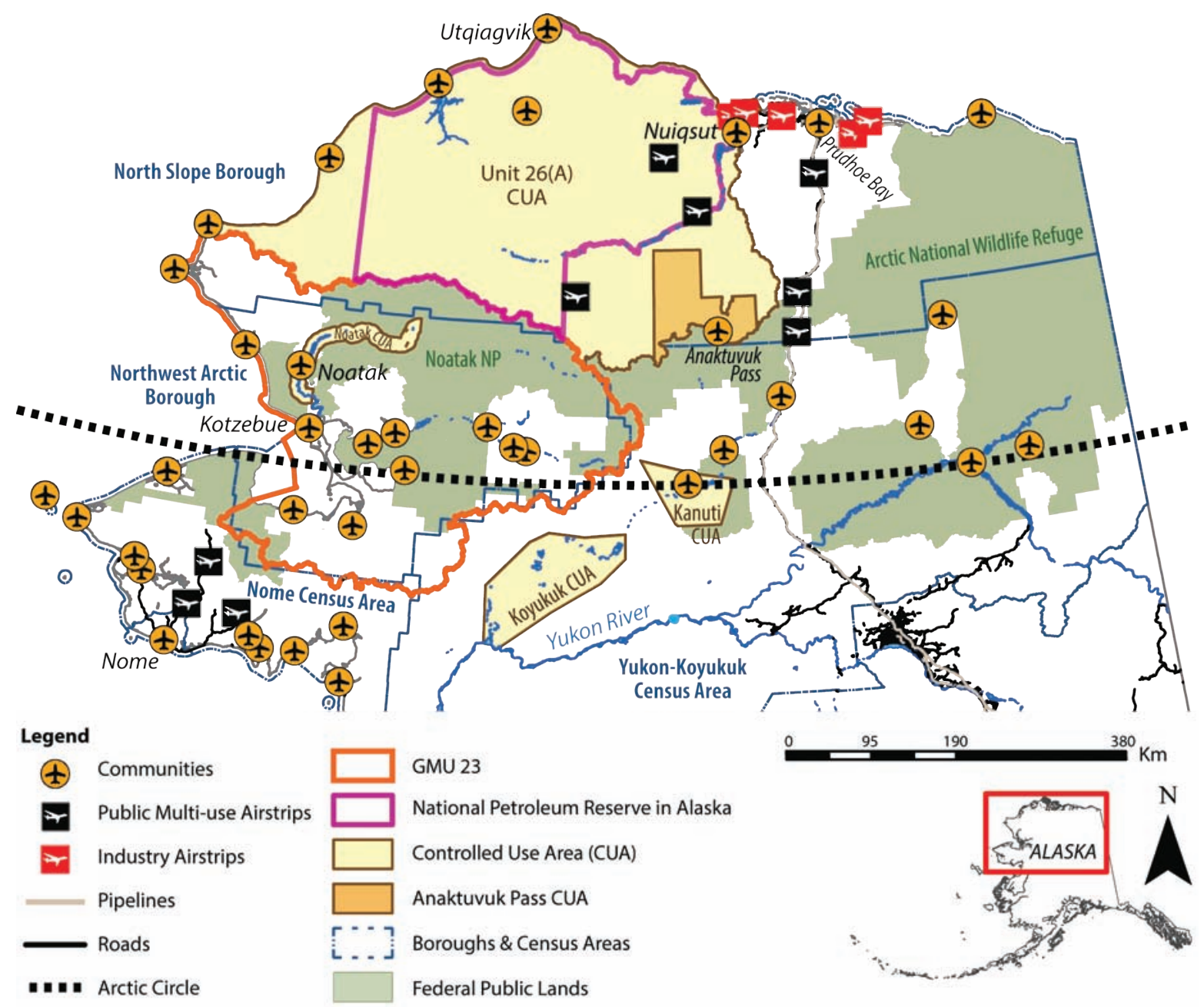

FIG. 1. Map of Alaska's North Slope and the eight rural communities that reside there. The ninth settlement of Prudhoe Bay is a non-Native township that was built to support oil and gas development in the Prudhoe Bay oilfield. Also depicted are airstrips, state oil and gas units (red outlines) and the National Petroleum Reserve-Alaska (pink outline). The Brooks Range delineates the southern border of the North Slope. Source layers are available at the Alaska State Geospatial Clearinghouse managed by Alaska Department of Natural Resources (http://www.asgdc.state.ak.us/) and the Bureau of Land Management Alaska Spatial Data Management System (https://sdms.ak.blm.gov/sdms/download.html).

caerulescens, Somateria spp.) and terrestrial mammals like caribou, moose (Alces alces), grizzly bear (Ursus arctos), wolf (Canis lupus), and fox (Vulpes vulpes, V. lagopus).

Five national parks, preserves, and monuments and three national wildlife refuges (the largest being the Arctic National Wildlife Refuge) encompass around $30 \%\left(166854 \mathrm{~km}^{2}\right)$ of the total land area in Arctic Alaska (approx. $570000 \mathrm{~km}^{2}$, Fig. 1). The National Petroleum Reserve-Alaska (NPR-A) - an area reserved by the federal government since 1923 for oil resource developmentspans another $16 \%$ of the region (approx. $92300 \mathrm{~km}^{2}$, Fig. 1). The Arctic Alaska region is under differential management by the North Slope and Northwest Arctic Boroughs, the state of Alaska, the National Park Service (NPS), the U.S. Fish and Wildlife Service (USFWS), and the Bureau of Land Management (BLM). Alaska Native regional and village corporations also are significant landowners in the region.

Arctic Alaska is mostly roadless, except for the Dalton Highway (Fig. 1), small road networks around villages, and roads that connect oil developments on the North Slope. Industrial development occurred within the last four decades, beginning with the discovery of oil at Prudhoe Bay (Fig. 1) in 1968 and expanding rapidly during the end of the 20th century. The westernmost development is on state lands $119 \mathrm{~km}$ from Prudhoe Bay on the Colville River Delta, forming a complex of five oil developments (well pads and connecting roads) known as the Alpine Satellite Development Project (ASDP) and operated by ConocoPhillips Alaska, Incorporated. The first developments on federal lands, leased by the BLM, are underway in the northeast corner of the NPR-A west of the Colville River delta. Within the Greater Mooses Tooth (GMT) unit, two drill sites are permitted for construction approximately $22.5 \mathrm{~km}$ west (GMT 1) and $32.2 \mathrm{~km}$ southwest (GMT 2) of the ASDP central facility. Most recently, the Tax Cuts and Jobs Act of 2017 (U.S. Public Law 115-97) included a provision that opens $6070.3 \mathrm{~km}^{2}$ in the Alaska National Wildlife Refuge (i.e., the 1002 area) to oil and gas drilling. 
Outside of oil and gas development, Arctic Alaska remains largely undeveloped. The region is sparsely populated by eight rural communities comprised predominantly of Indigenous Alaska Native people (i.e., Iñupiat Eskimo, Gwich'in, Athabascan, and some Yu'pik) who rely on seasonal harvests of fish, wildlife, and flora for nutrition, food security, and sociocultural well-being (Galginaitis and Petterson, 1990; Nuttall et al., 2005; Bacon et al., 2011; Alaska Federation of Natives, 2012; Berkes, 2012; Brubaker et al., 2014). Such customary and traditional use of wild resources is classified as subsistence under state and federal law (Alaska Statute 16.05.258; Alaska National Interest Lands Conservation Act; Public Law 96-487, Title VIII). The average village population is around 304 residents, excluding the three largest villages, Utqiagivik (formerly Barrow, population approx. 4380), Nome (population 3595), and Kotzebue (population 2885). Each community has a small airstrip that serves commercial, cargo, and some private aircraft. The influx of industrial and civil development transformed rural hunter-gatherer economies into mixed subsistence-cash economies. Now, village residents simultaneously engage in commercial markets and wage employment while maintaining some level of subsistence harvest practices and social networks for distributing their harvest (Brower, 1980; Wolfe, 1984; Magdanz et al., 2016; BurnSilver et al., 2017).

Military-industrial expansion during WWII and the Cold War era established aircraft operators in Arctic Alaska to support military defenses and industrial development. The role of aircraft has since diversified to provide commercial transportation and cargo services among rural communities, access for nonlocal people to recreational and harvest opportunities, and continued support for resource development. Although aircraft provide services for rural communities and support the economic benefits conferred by oil development, rural communities remain concerned about the impacts to traditional ways of life. Because of the concentration and rapid expansion of recent development, this region has received considerable attention from the scientific community for research on anthropogenic impacts to Arctic ecosystems. Increased research activities have generated another source of low-flying aircraft traffic across the region.

\section{Systematic Search Methods}

To determine the degree to which aircraft conflict was assessed by a representative sample of the available literature, we conducted a series of four searches on Google Scholar using the following search strings: combinations of four to six key words: "aircraft noise" or "aircraft disturbance," "wildlife" or "humans," "Arctic" or "Alaska," and "annoyance" or "behavior." The four search strings were:

\footnotetext{
1. "aircraft disturbance," "subsistence," "Arctic," OR "Alaska"

2. "aircraft noise," "wildlife," "Arctic" OR "Alaska"
}

\author{
3. "aircraft noise," "humans," "Arctic," "annoyance," \\ "rural," OR "subsistence" \\ 4. "aircraft noise," "humans," "annoyance," OR "behavior"
}

The purpose of the fourth search was to provide a relative comparison between the literature on human-aircraft relations in urban environments or areas outside of the Arctic with that in rural or subsistence communities in the Arctic.

For each search, we mined the first 10 pages of results with 20 items per page. A total of 800 articles were examined across the four searches. We saved relevant articles to 'My Library' on Google Scholar and tagged them with the corresponding search string. We excluded results that contained one or more of the key words only in a citation rather than the main text. An article was deemed relevant if it specifically discussed the impacts of aircraft on wildlife or human populations. For those search results that dealt broadly with anthropogenic noise or disturbance (e.g., review papers), we excluded articles that simply listed aircraft as a source of transportation or motorized noise. We then determined the proportion of relevant articles that dealt with Arctic or non-Arctic regions.

We included gray literature in our selection of relevant results because it serves as a practical measure of knowledge and perceptions on the issue as compared to peer-reviewed studies. By our definition, gray literature includes articles not published in a peer-reviewed journal. For example, our search generated government agency reports, theses and dissertations, environmental impact statements, news or magazine articles, and reports from non-governmental organizations like the National Resources Defense Council (NRDC) or from tribal consortia like the Inupiat Community of the Arctic Slope (ICAS).

After completing all four searches, we compared the distribution of articles between the ecological and social science disciplines by coding each saved article with one of three categories-Social Science, Ecology, or Otherbased on the journal in which it was published and the empirical approach applied. We determined the proportion of results within each category that was peer-reviewed or gray literature and the proportion concerning Arctic regions. We also examined the distribution of articles among subcategories related to the primary discipline (e.g., psychology, human health, policy) or the taxa (e.g., marine mammals, ungulates, birds) of interest. This comparative approach allowed us to quantify the degree of scientific attention that has been devoted to aircraft-harvester interactions in the Arctic and to determine the realm of inquiry within which that attention has been focused. We provide a summary of the literature results from our searches in online Appendix 1.

\section{RESULTS}

Of the 800 articles that we examined using Google Scholar, we found 180 articles $(22.5 \%)$ to be relevant to our 


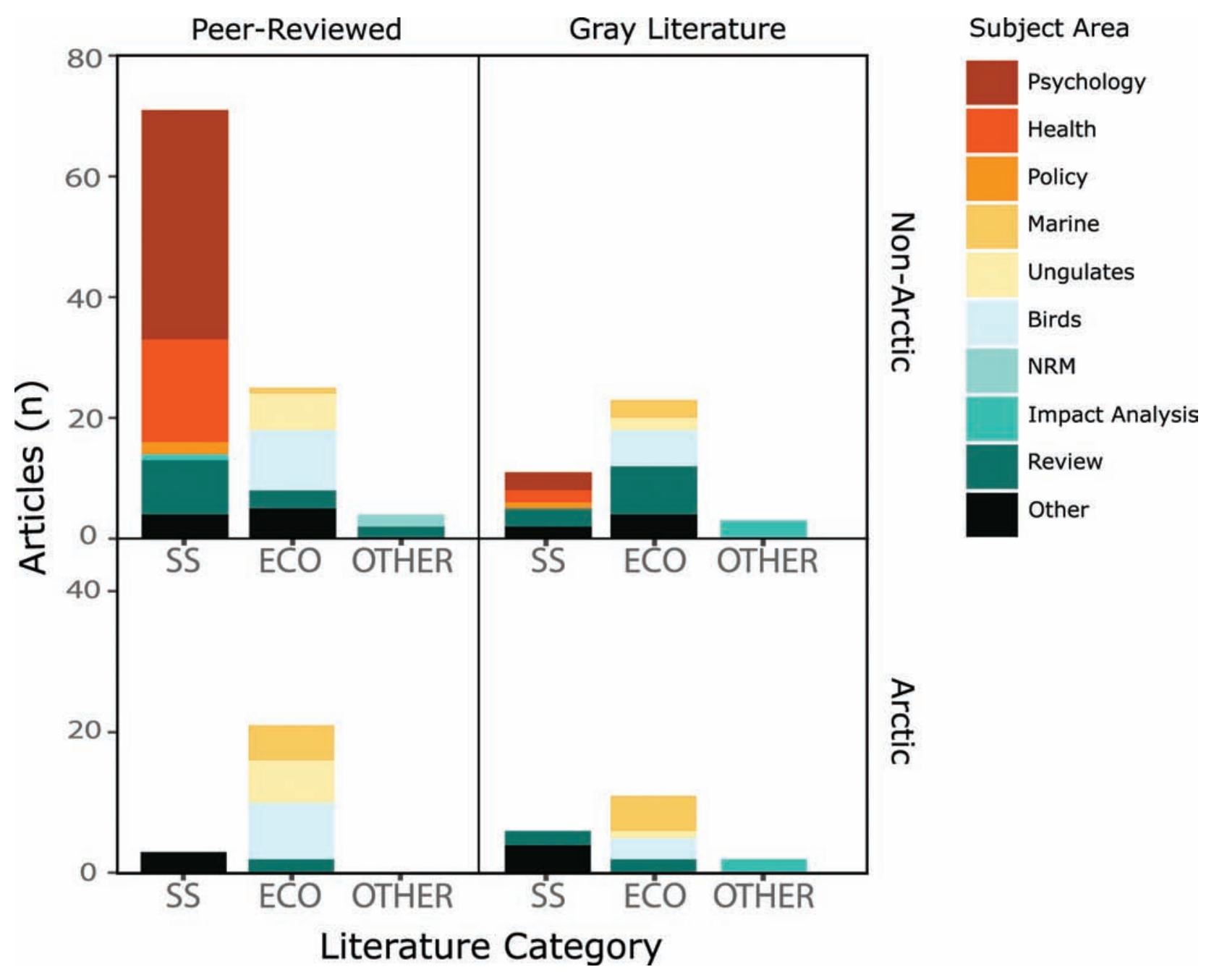

FIG. 2. Results from a systematic search of literature available on Google Scholar for the effects of aircraft noise on human communities and wildlife. Relevant articles were categorized into three main categories based on scientific discipline and empirical methods used: Social Science (SS), Ecology (ECO), or Other (OTHER). The Other category included articles regarding broad environmental and/or human impact analysis, soundscape ecology and management, or noise pollution. These categories were then divided into Peer-Reviewed or Gray Literature outlets. Gray literature encompasses articles not published in a peerreviewed journal, including but not limited to government reports, theses and dissertations, book chapters, news articles, or press releases. We examined each article closely for its primary subject area and relevance to Arctic regions or Alaska ("Arctic"/ "NonArctic").

research question and analysis, explicitly discussing the impacts of aircraft to human or wildlife populations or both.

Of the relevant articles, $91(50.5 \%)$ fell under the Social Science category and $80(44.4 \%)$ fell under Ecology. We categorized nine articles (5.0\%) as "Other," which comprised articles that assessed the impacts of aircraft activities on both humans and wildlife or dealt with aircraft noise in natural resource management (NRM). Among Social Science articles, $74(81.3 \%)$ were published in a peer-reviewed journal (Fig. 2). Studies on human health and psychology (e.g., annoyance, stress, and the cognition of schoolchildren in response to aircraft) dominated the Social Science category $(62.6 \%, n=57$, Fig. 2), all of which focused on urban or developed communities outside of the Arctic. A total of nine Social Science articles (9.9\%) dealt with Arctic regions, but only three (3.3\%) were found in peer-reviewed journals (Fig. 2). These discussed the role of traditional harvest practices in a mixed economy and interactions among energy development, tourism, and Indigenous peoples.
The Ecology category contained 46 (57.5\%) peerreviewed articles, of which $21(45.7 \%)$ concerned Arctic regions or wildlife (Fig. 2). The remaining Ecology gray literature $(\mathrm{n}=34,42.5 \%)$ contained 12 Arctic-relevant articles (35.3\%). Of any Ecology articles relevant to Arctic species, $10(30.3 \%)$ regarded the effects of aircraft noise and offshore development on marine mammals. Another 11 articles (33.3\%) focused on aircraft impacts to avian species in the Arctic. Caribou were the study species in eight articles $(24.2 \%)$ on Arctic wildlife. Only one peerreviewed Ecology article (Fullman et al., 2017) mentioned aircraft impacts on traditional harvest practices, but did so briefly. Aircraft impacts to caribou remained the focus of this study.

Within the Other category, four articles (44.4\%) were peer-reviewed and five (55.5\%) belonged to the gray literature. Only two articles $(22 \%)$ concerned Arctic environments and both were published in the gray literature (Fig. 2). 
In total, Arctic literature comprised $24.4 \%(n=44)$ of our relevant search results. Three quarters $(75 \%, \mathrm{n}=33)$ of Arctic literature fell under the Ecology discipline, concentrated on the impacts of aircraft and associated human activities on Arctic wildlife populations. Almost half of Arctic-relevant articles $(45.5 \%, \mathrm{n}=20)$ fell into our definition of gray literature, including government reports, theses or dissertations, press releases, and open letters by tribal organizations.

The issue of conflict between aircraft users, sport hunters, and subsistence harvesters arose only in four gray literature articles (7.1\% of gray literature, $2.2 \%$ of total). These papers include two technical reports from the Alaska Department of Fish \& Game concerning harvest use on the Noatak and Kobuk Rivers, a dissertation on local harvester perceptions of aircraft transporters and sport hunting in Noatak National Preserve, and a resolution by the ICAS to support the designation of sensitive traditional harvest areas. We did not find mention of aircraft-harvester conflict elsewhere. Not a single peer-reviewed article in our sample focused on the issue of aircraft disturbance to rural Arctic harvesters, suggesting that rigorous research for dissemination to a broad scientific audience is needed.

\section{DISCUSSION}

Our analysis demonstrates that, incongruous with the level of concern expressed by Arctic residents, a severe deficiency exists in the peer-reviewed literature regarding research focused on the sociocultural consequences of aircraft disturbance to rural Arctic communities. Changes in the land use and behavior of harvesters themselves (e.g., harvester avoidance of high-traffic areas) have not been reported in peer-reviewed outlets by the ecological or social science research communities. Objective studies quantifying the extent of aircraft activity in traditional harvest areas do not exist, nor do spatially and temporally explicit studies on actual aircraft-harvester interaction. We speculate that these key findings are related to the complex and variable interactions among harvester behavior, wildlife movements, and aircraft activity levels that make it difficult for scientists to investigate, disentangle, and estimate cause-and-effect relationships.

The limited gray literature we found that addressed aircraft-harvester conflicts in the Arctic took social science approaches to examine the issue (e.g., surveys, interviews, and data or literature synthesis). Although some peerreviewed literature examines the displacement of Arctic migratory mammals by industrial and vehicular activity, ecological studies have not yet taken an integrated, wholesystem approach to understand how aircraft-wildlifeharvester interactions affect the traditional harvest practices of rural communities.

The research community remains highly selective in the issues it has chosen to investigate in the Arctic. Ecological research regarding aircraft or associated human disturbances appears to prioritize the impacts on wildlife-especially birds, ungulates, and some marine species - while social science has prioritized the impacts of aircraft noise on human psychology, cognition, and health in urbanized areas. That body of research focused on the impacts on human communities has largely neglected economic and sociocultural impacts to rural, often Indigenous and marginalized, communities.

Why are more researchers not engaging with this issue in rural Arctic Alaska? This question is particularly pertinent given the rising impetus to incorporate traditional ecological knowledge into Western science across the Arctic (e.g., Olsson and Folke, 2001; Berkes et al., 2007; Huntington et al., 2011; Parlee et al., 2014; Polfus et al., 2016) and globally (e.g., Moller et al., 2004; Brook and McLachlan, 2008; Silvano and Valbo-Jørgensen, 2008; Firn et al., 2017; Bélisle et al., 2018). The obvious human dimensions of this problem would supposedly attract social scientists to study its causes and consequences or to examine whether the conflict is fundamentally embedded in the legacy of colonialism. The precariousness of discussing colonialism from a non-Indigenous perspective may deter social scientists from investigating Indigenous social conflicts. Despite this potential hindrance, baseline studies on annoyance levels or social attitudes towards aircraft have not been conducted in rural Arctic communities.

Government reports, public testimonies, and a few historical records and ethnographies currently contain the most information about aircraft-harvester conflict in Arctic Alaska. Much of this gray literature did not come up in our systematic search of Google Scholar, which indicates that our review was unable to capture all relevant information and further supports the need to disseminate research on this topic in peer-reviewed outlets. During our systematic search, we did not encounter public records from the Federal Subsistence Board, Regional Subsistence Advisory Councils, Alaska Board of Game, or the NPR-A Subsistence Advisory Panel. Many transcripts from the meetings of these groups are available online from the past decade (Table 1), but these files were not retrieved by Google Scholar. Specific comments or agency press releases on aircraft are either not easily extracted from the available material or are not considered a retrievable source by Google Scholar. We had to visit individual websites and navigate through their menus to find meeting transcripts, board or committee actions, or other applicable documents. The BLM is the only known agency to mine through four decades of public records from their own committee, the NPR-A Subsistence Advisory Panel, extract comments regarding aircraft-subsistence conflict, and summarize the major issues (Table 1). We have compiled a table of public records that issue actions or recommendations to address the conflict between low-flying aircraft and subsistence users. We also provide direct links where these records can be accessed (Table 1).

Because of the paucity of peer-reviewed literature, in the following sections we rely heavily on gray literature to 


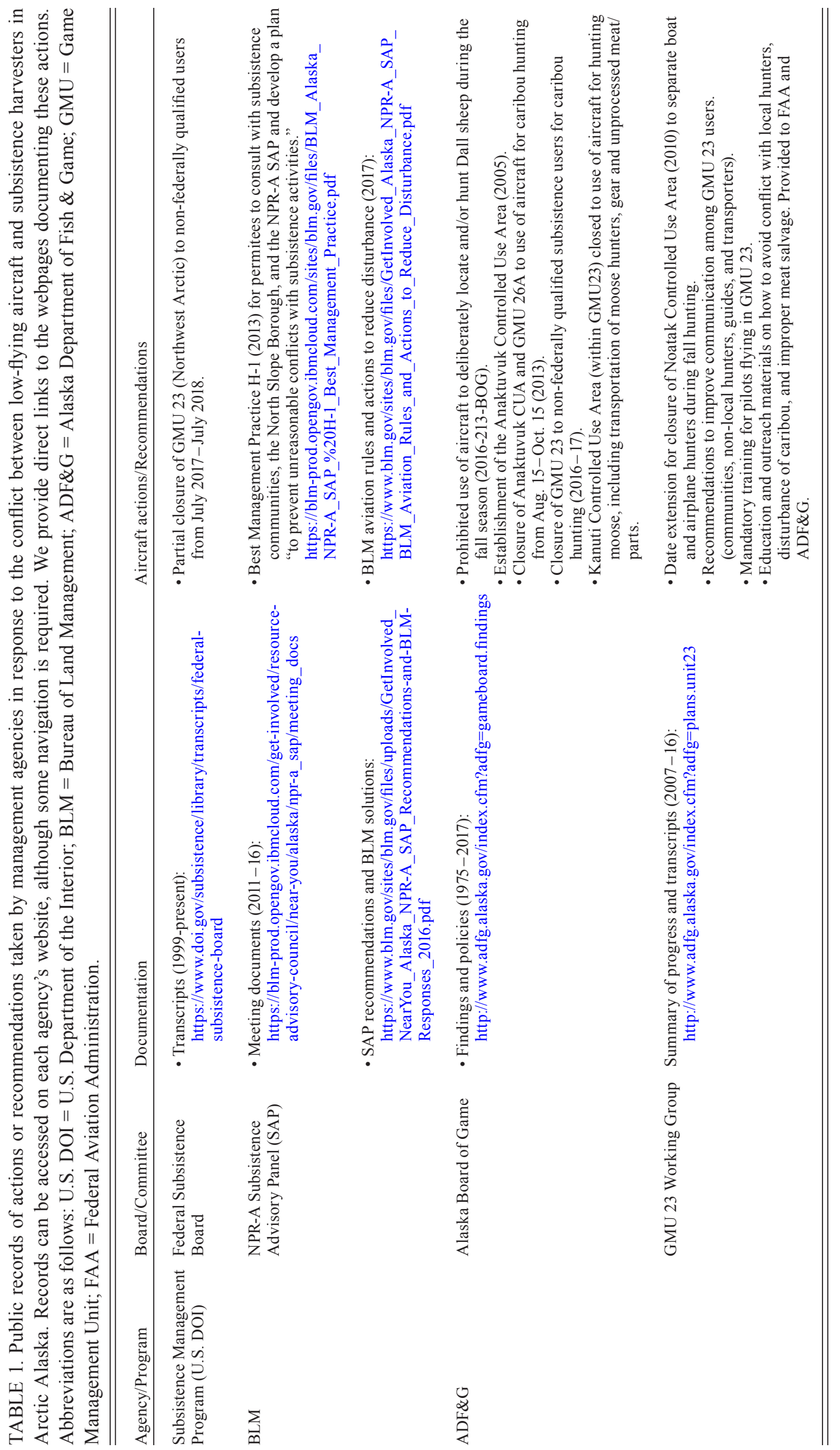


draw inferences about the behavior of traditional harvesters and their attitudes toward aircraft. We examine why aircraft constitutes a disturbance to harvesters from rural Arctic communities and explore potential opportunities for mitigating the impacts of aircraft on traditional harvest practices.

\section{Persistence of Aircraft-Subsistence Harvester Conflict}

The available literature tells us that the essence of subsistence harvester frustration with aircraft is twodimensional: aircraft (1) degrade the harvest experience by interrupting seclusion and traditional expectations and (2) threaten harvest opportunities by spooking caribou, diverting hunters, and competing for resources. Encounters with aircraft detract from the aesthetic quality and seclusion that many rural Alaska residents expect to experience while harvesting wild resources (Cuomo et al., 2008; BLM, 2014; BLM SAP, 2014; Halas, 2015). Seclusion contributes strongly to the satisfaction of both subsistence and sport harvesters from across the U.S., including Alaska (Heberlein, 2002; Vaske and Shelby, 2008). It is also an influential value to the experience of national park visitors; the sight and sound of aircraft (particularly helicopters) degrade park visitor perceptions of a pristine landscape, even at relatively low sound levels (40 dBA, Mace et al., 1999; Bell et al., 2010). As Mace et al. (1999:226) describe, sounds "perceived as avoidable and abnormal to the situation" are more likely to cause annoyance. Rural harvesters may feel marginalized because they have little control over flight times and trajectories occurring in their traditional use areas, which amplifies their general frustration toward aircraft (Hatfield et al., 2002). Data on flight paths over harvest areas are not regularly compiled from aircraft users and not readily available or communicated to local communities. The lack of these data restricts the capacity of both communities and researchers to predict where aircraft will intersect with harvest activities.

Outside aircraft sources that compete directly with harvesters for local resources generate an additional level of frustration for local communities. Nonlocal sport hunters-allured by world-class hunting opportunities for wildlife, including moose, caribou, Dall sheep (Ovis dalli dalli) and grizzly bear-hire private pilots to transport them around Arctic Alaska via small fixed-wing aircraft. A substantial portion of the available literature has focused on this competition between local subsistence harvesters and nonlocal, aircraft-transported hunters in and around Noatak National Preserve (within the NWAB, Fig 1). Most local Noatak residents travel by boat and attempt to harvest caribou as they cross the river in known migratory regions (Georgette and Loon, 1998; Halas, 2015). Aircraft transporters and nonlocal hunters displace Noatak harvesters from these traditional sites, thereby competing for caribou and other wildlife during the fall hunting season (Georgette and Loon, 1998).
Halas (2015) documented the local perspective (i.e., traditional ecological knowledge) of this conflict using mixed participatory research methods. Local harvesters perceived changes in caribou migration to be more negatively driven by the increasing presence of aircraft and nonlocal sport hunters than by climate change, predation, and habitat change. Negative impacts included spooking or diversion of caribou, aircraft "swooping" or circling over caribou, dropping hunters directly in the path of caribou groups, and hunting practices that appear disrespectful (e.g., littering, moving a kill, discarding or spoiling meat, clustering of camps) or naïve (e.g., shooting the leader of a group of caribou; Padilla and Kofinas, 2014). Encounters with aircraft were more often reported by local harvesters to reduce physical harvest success, whereas encounters with nonlocal hunters detracted from the perceived quality of the harvest experience.

On the other side of the issue, nonlocal sport hunters who use aircraft transporters to access Noatak National Preserve did not perceive any conflict to exist among their activity, aircraft use, and local subsistence harvesters (Fix and Ackerman, 2015). Nonlocal sport hunters were unaware of local subsistence harvest practices and use areas. The lack of awareness on the part of nonlocal hunters (and possibly transporters) and the value differences between nonlocal and local subsistence hunters fundamentally contribute to the persistence of conflict in and around Noatak National Preserve (Steinacher, 2006; Halas, 2015).

Similar competition or conflict with nonlocal, sporthunting aircraft persists around Anaktuvuk Pass, an insular rural community in the Brooks Range (Fig. 1). Without access to marine resources, Anaktuvuk Pass relies on the annual caribou migration for most of its harvested food supply (BLM SAP, 2010, 2016), and residents blame sport-hunting aircraft for shifting caribou away from the traditional routes near their village (WAH Working Group, 2016). Although Fullman et al. (2017) reported that sporthunting activity did not appear to inhibit caribou migration in northwestern Alaska (Noatak National Preserve), temporary effects could still alter caribou availability to individual harvesters and compromise food security for insular communities (U.S. Department of the Interior, 2017; BLM, 2017).

To our knowledge, there is no peer-reviewed study that documents direct interference of aircraft with harvest success, but harvester avoidance and wildlife diversion are reported to reduce harvest opportunities through increased costs to travel farther for longer periods of time in pursuit of wildlife (Kruse et al., 1982; NRC, 2003; Nuttall et al., 2005; Hansen et al., 2013; NSB, 2014). The apparent stability in annual harvest rates for a given Arctic community could be explained by a few super hunters or super households who have the resources (e.g., income, equipment, and time) to travel farther and more often, harvest more wildlife, and then share the harvest among family and community networks (Magdanz et al., 2002; Wolfe et al., 2009). 
Survey-based studies in the gray literature have only recently begun to include questions that specifically ask why harvesters avoid parts of their traditional lands (Stephen R. Braund \& Associates, 2016, 2017). Over half $(58 \%)$ of surveyed harvesters from the community of Nuiqsut report avoiding traditional lands because of heightened motorized activity, industrial development, or safety concerns (Stephen R. Braund \& Associates, 2016). In 2015, helicopter traffic accounted for half of all reported impacts to harvest activities around Nuiqsut, with "impact" interpreted as the dispersion of caribou that resulted in an unsuccessful hunt (Stephen R. Braund \& Associates, 2017). Helicopters are generally perceived to be more disruptive than fixed-wing aircraft by hunters (BLM, 2014, 2017; Stephen R. Braund \& Associates, 2017) and recreators alike (Mace et al., 1999), unless fixed-wing aircraft fly low and harass wildlife (i.e., by circling over or following; Napageak, 2000; U.S. Army Corps of Engineers, 2016) or exhibit higher use than helicopters in a given region (e.g., transporter aircraft in Noatak National Preserve).

Caribou comprise the third dimension to consider in the aircraft-harvester system. In contrast to the social dimension, our Ecology literature contained 59\% peerreviewed articles on aircraft-wildlife interactions, of which $29 \%$ focused on the responses of caribou or other ungulates (including review articles). Extensive research has been conducted on the biology of Alaska's caribou herds by public entities (Skoog, 1968; Davis, 1980; Klein, 1991a, b; Bergerud, 1996; Valkenburg, 2001; Cameron et al., 2005; Carroll et al., 2005), privately contracted companies (Murphy and Lawhead, 2000; Prichard and Murphy, 2004), and research collaborations (Wilson et al., 2012). Empirical studies confirm that caribou flee and become restless when exposed to low-flying aircraft (McCourt et al., 1974; Calef et al., 1976; Maier et al., 1998). Helicopters tend to elicit greater and more recurrent responses than fixed-wing or jet aircraft, especially at altitudes below $200 \mathrm{~m}$ (Harrington and Veitch, 1991; Anderson, 2007). Some evidence suggests that caribou habituate to or tolerate aircraft during highstress seasons (e.g., insect harassment, rut, winter; Geist, 1971; Murphy and Curatolo, 1987; Vistnes et al., 2008) but maternal females exhibit less tolerance during calving (Reimers and Colman, 2006). Populations that inhabit areas under regular air traffic (e.g., near airports or military bases) may habituate to aircraft noise (Bowles, 1995; Maier et al., 1998). Habituation is less likely to occur when aircraft fly seasonally or intermittently (e.g., in rural Arctic regions), or follow caribou for tourism or survey purposes (Harrington and Veitch, 1991; McClure et al., 2013).

Other motorized activity associated with industrial infrastructure has displaced caribou herds from their historical range (Braem et al., 2011) and shifted the seasonal timing of migration (Mahoney and Schaefer, 2002). Lowflying aircraft may also shift caribou migration routes, but the annual variability in both caribou migration routes and aircraft activity levels makes it difficult to determine how caribou distribution responds to aircraft alone. Published research has not yet examined aircraft disturbance at a spatiotemporal scale necessary to conclude long-term causal relationships (Vistnes and Nellemann, 2008). This complex and wide-ranging system does not seem to offer a simple, practical solution to resolve aircraft-harvester conflict. However, regulatory bodies have begun to enact mitigation measures at federal, state, and local levels in response to subsistence harvester concerns.

\section{Existing Regulations and Mitigation Strategies}

Evidence in the gray literature combined with repeated public testimony on aircraft-harvester conflict prompted the Alaska Board of Game to issue seasonal closures of Game Management Units (GMUs) 23 and 26A (Fig. 1) to non-subsistence users and to aircraft activity (Table 1). The Alaska Board of Game acknowledged in 2016 that aircraft have "disrupted the efforts of other hunters through displacement of animals and also lowered the quality of experience for other hunters who do not use aircraft" (Alaska Board of Game, 2016:1). In 2017, the Federal Subsistence Board issued partial closures of GMUs in the NWAB (Table 1), recognizing that "the short-term effects of aircraft on caribou behavior can negatively affect hunting success and harvest" (U.S. Department of the Interior, 2017:1). These actions face unquantified outcomes, limited enforcement capacity (e.g., 45 Alaska Wildlife Troopers patrol the Northern detachment, a region wider than Arctic Alaska as defined in this study), and limited authority over aircraft users.

The Federal Aviation Administration (FAA) holds the ultimate authority to regulate airspace use and pilot behavior. Existing FAA regulations focus heavily on flight altitudes over different classified regions (Table 2). A brief search of the Code of Federal Regulations ("CFR," Legal Information Institute, 2018) revealed that the FAA is not concerned about small aircraft or helicopter altitudes in Alaska. Special flight rules over national parks and tribal lands established by the National Parks Air Tour Management Act (2000) exclude the state of Alaska and Alaska Native lands. For rural or sparsely populated areas, a single altitude restriction of $152 \mathrm{~m}(500 \mathrm{ft})$ exists over any person, vessel, vehicle, or structure, but this regulation does not mention wildlife (Table 2). Decisions about altitude in rural regions are often left to the pilots' best judgement, particularly during low visibility or hazardous conditions.

Amid the FAA's disregard toward aircraft activity in rural Arctic Alaska, localized regulatory entities have issued restrictions on flight behavior to minimize aircraft impacts to subsistence harvests. Since lands are differentially managed by federal, state, and municipal agencies, these recommendations vary considerably across the region. For instance, small aircraft and helicopters are restricted to a minimum altitude of $305 \mathrm{~m}$ over caribou herds by the Bureau of Land Management (BLM) or to $457 \mathrm{~m}$ by state of Alaska and Borough codes (Table 2). Most agencies recommend altering flight activities and 
140 • T.R. STINCHCOMB et al.

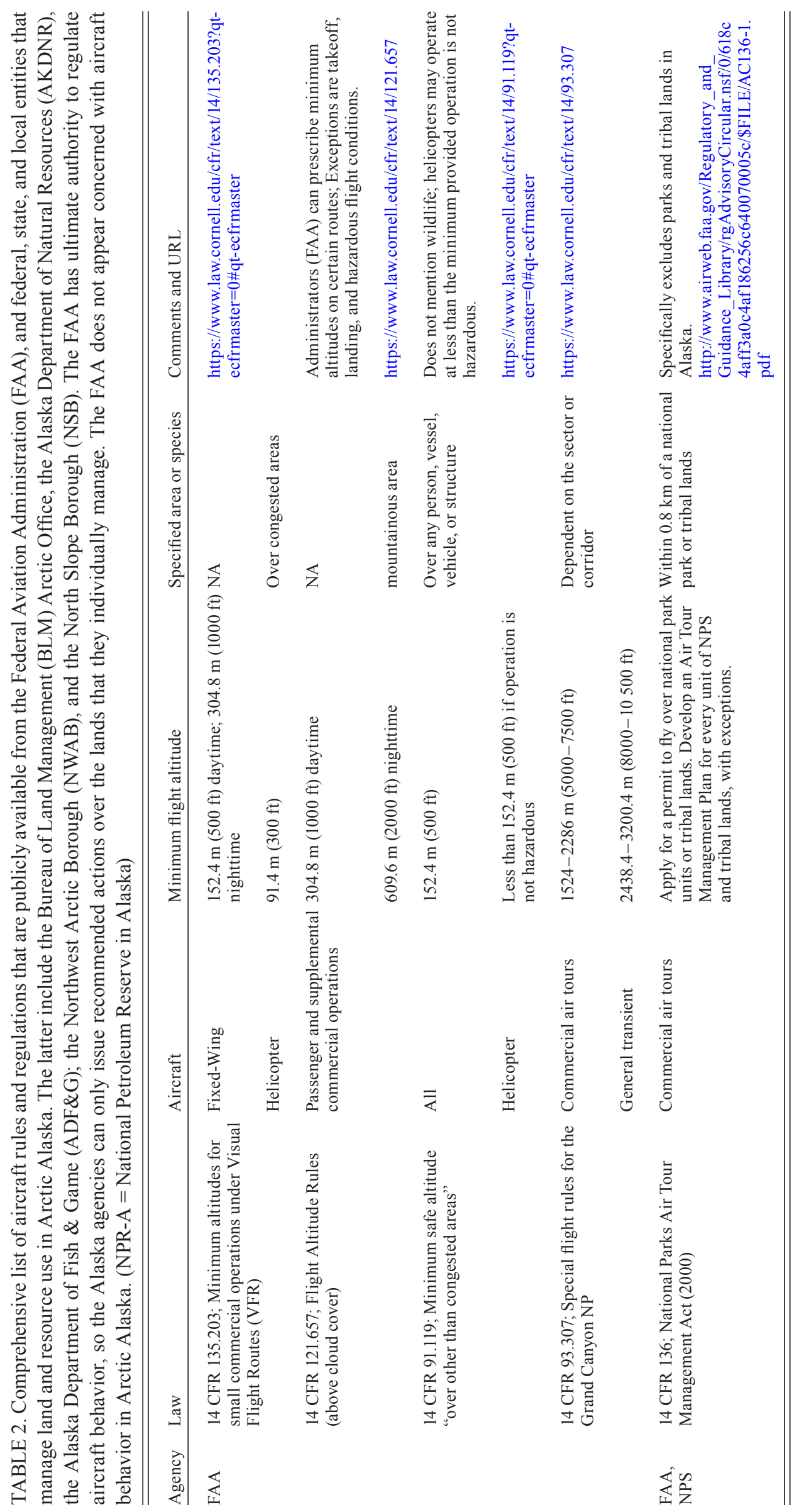



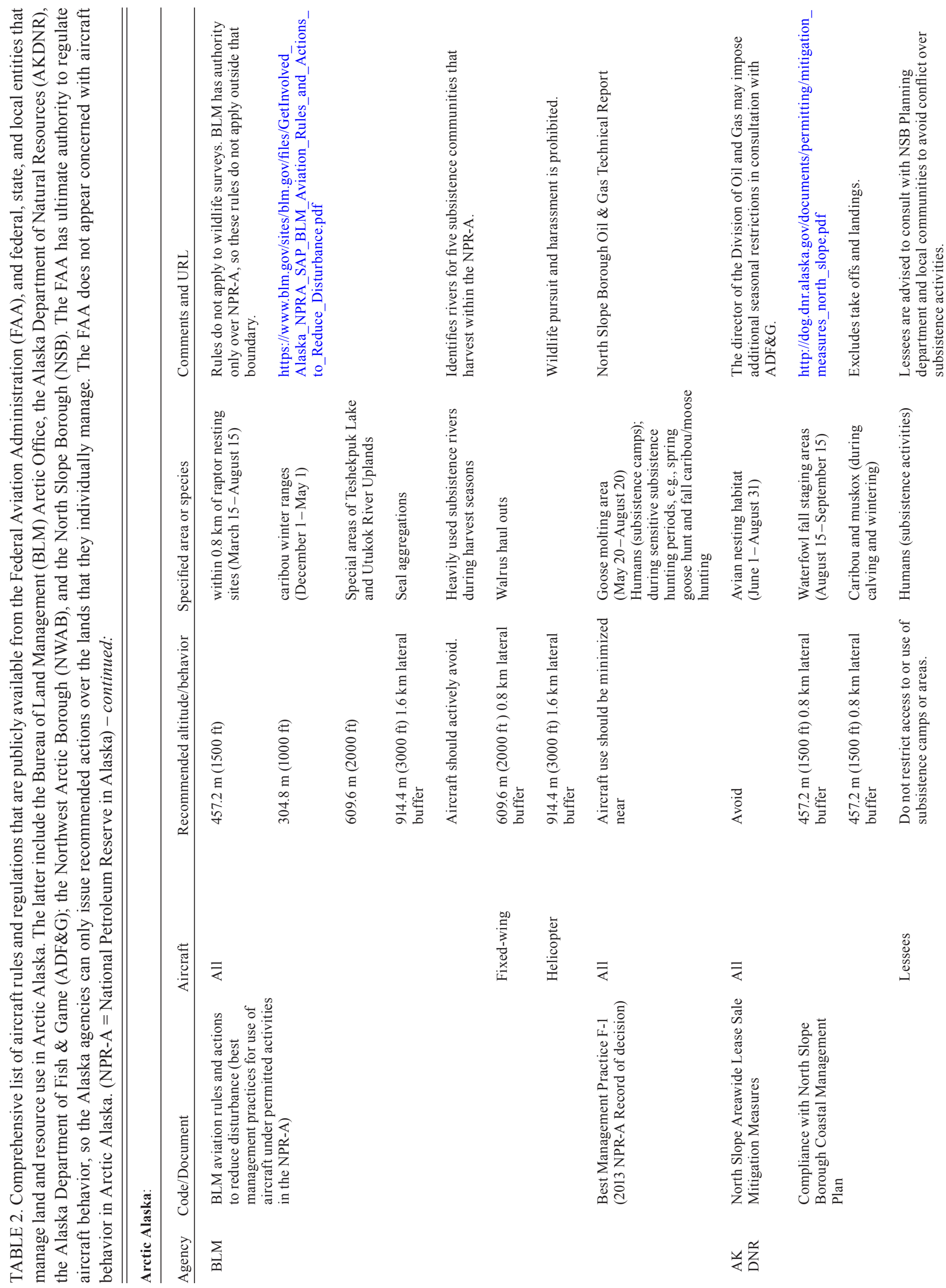


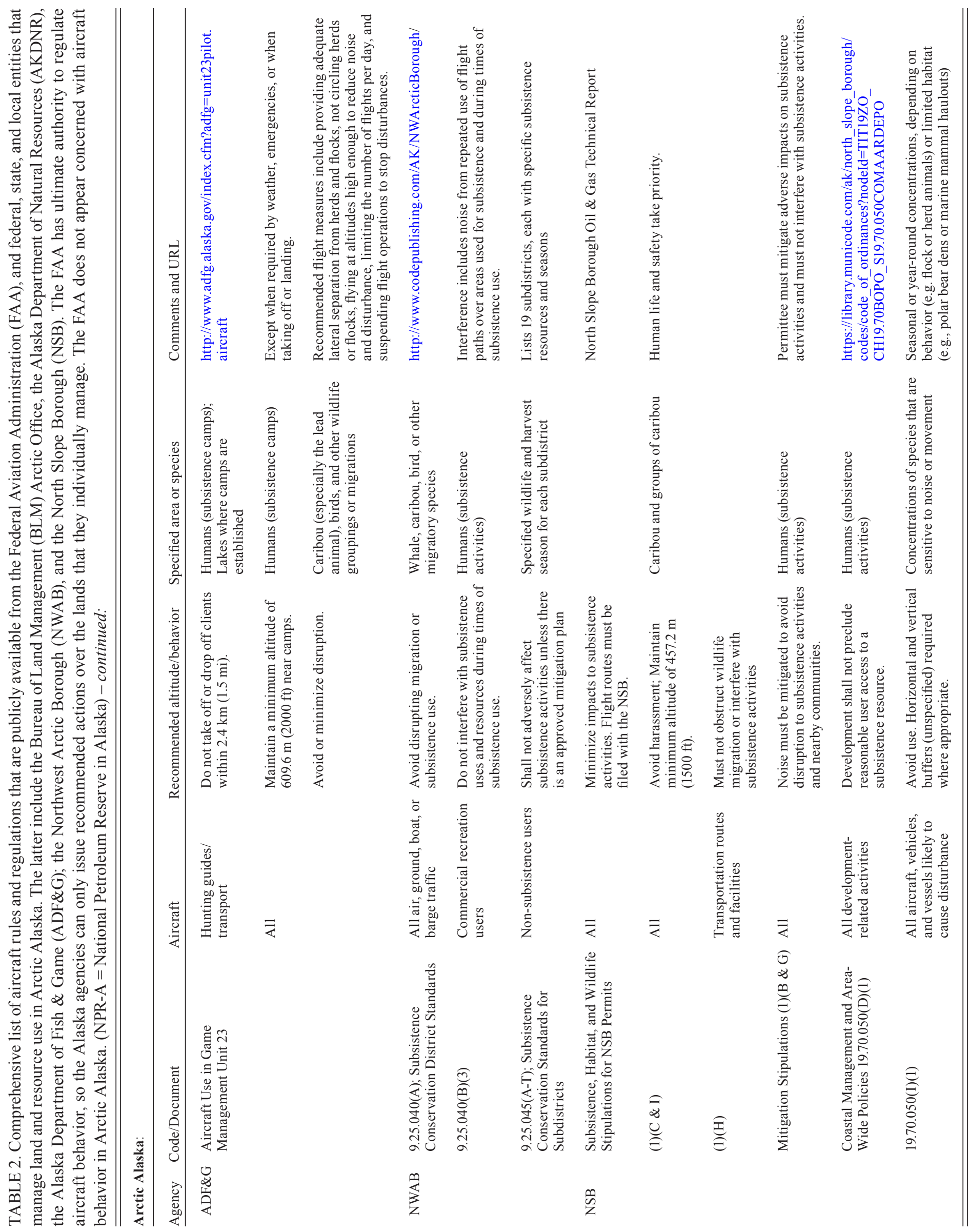


avoiding the use of aircraft over specified subsistence areas or during specific harvest periods (Table 2). The NWAB municipal code provides the most thorough designation of Subsistence Conservation Subdistricts ( $\$ 9.25 .045(\mathrm{~A}-\mathrm{T})$, Table 2) that aircraft and nonlocal users should avoid. Similar designations of sensitive tribal areas (Wolfe, 2013) and heavily used subsistence rivers (BLM, 2017) exist within the NSB, but they have not yet been integrated into the NSB municipal code (Table 2). Minimum altitudes, lateral distance restrictions, and designated areas to avoid are likely the easiest rules for operators to follow, which would explain their prevalence at all regulatory levels. However, the apparent inconsistency in flight rules and permit stipulations among municipal, state, and federal levels could lead to confusion and potential negligence for any rules other than FAA minimum altitudes.

The efficacy of state and local recommendations to mitigate aircraft-harvester conflict has not been formerly evaluated. Yet repeated requests from harvesters and community leaders for aircraft to fly higher (Napageak, 2000; Brower, 2003) suggest that either the minimum altitude is too low to be socially acceptable or pilots are flying too close to wildlife and harvesters. Conflict is persisting, particularly during subsistence harvest seasons or wildlife migrations, indicating that current rules and regulations are not adequately addressing this issue. The differential jurisdiction of governmental agencies poses a substantial barrier to enforcing aircraft compliance: the FAA has sole authority to place legal restrictions on flight behavior, and sole authority over private aircraft. The BLM, state, and Borough agencies can only issue recommendations and reporting requirements for permitted aircraft over their specific jurisdictions during specific times of the year. Regulatory agencies will need to develop other, more indirect mitigation strategies to work around these bureaucratic barriers.

Perhaps the most frequent recommendation during public hearings and advisory panel meetings is the need for communication between aircraft users and local communities. Community members express the need to be informed directly and regularly about when and where aircraft are occurring and request the release of scheduled flights and tracking information (BLM, 2014). Regulatory agencies and stakeholders appear to be working towards greater transparency and collaborative planning. Developing communication plans with local communities is an established measure to mitigate the social impacts of industry activities (BLM, 2015, 2017; NSB, 2015, 2016). Information on subsistence use areas and anticipated aircraft activity is disseminated annually to industry stakeholders and communities via permit applications, email, and social media. The NWAB municipal code recommends that industry representatives collaborate with affected communities during the permitting process for aircraft-supported activities (e.g., NWAB Municipal Code $\S 9.25 .090$ ), and NSB permit stipulations (Table 2) require flight routes and community-specific mitigation plans to be filed with the Borough. ConocoPhillips-Alaska Inc. has established several outreach meetings and call-in numbers to communicate the activity of their helicopters to the community of Nuiqsut and to coordinate activity with other industry and agency aircraft in the region.

Residents are invited to provide information about their harvest plans, but we do not know how many people use call-in numbers to voluntarily report their activities or report conflicts. Communication efforts need to be bidirectional, with pilots and aircraft users informed about current subsistence activities and potential impacts to harvest, and harvesters informed of the aircraft activity scheduled to take place in their harvest areas. Informing all parties of where conflict is likely to occur is a prerequisite for establishing effective conflict avoidance agreements, which leaders of rural Arctic communities identify as the most immediate strategy to protect access to traditional resources (Brown, 1979; NSB, 2015, 2016). However, parties involved need to evaluate whether information-based strategies result in active re-routing of flight paths and reduced conflict in harvest areas (Fix and Ackerman, 2015).

The efficacy of mitigation measures is limited further by the fact that much of the research conducted to understand changes in subsistence resources - and requested by agencies and local communities - requires the use of aircraft (BLM, 2014, 2017). Few viable alternatives exist to replace aircraft for surveying wildlife, monitoring environmental conditions, and reaching remote field sites. Although often suggested by community members (BLM, 2014), satellite remote-sensing (SRS) technologies can be too costly, complex, and time-intensive to integrate efficiently into research and monitoring programs. SRS implementation is also limited by the difficulties in retrieving an image for a specific area during a specific timeframe and identifying caribou or other wildlife against unpredictable environmental conditions and complex land cover.

An emerging technology that could potentially circumvent the expense and limitations of both SRS and aerial surveys is the small, unmanned aerial system (i.e., drone). The value of drones for wildlife surveys depends on the spatial accuracy, optics, and resolution of the sensors as well as the capacity of the drones to operate for extended periods in remote regions (Watts et al., 2010). However, the integration of infrared imaging into drones could improve detection rates in sub-optimal conditions, especially on flat and unforested landscapes like the Arctic tundra. Although drones are much quieter than propeller or rotary aircraft, they will fly lower to the ground, posing a potential, yet inconclusive, risk to wildlife (Christie et al., 2016).

FAA regulations currently hinder the proliferation of the drones in ecological research more than do any technological or practical limitations. The FAA restricts drones to line-of-sight operation by a person who has completed a thorough training and permitting process (14 CFR § 107), a significant barrier for population-scale surveys in vast remote areas. The FAA faces pressure from researchers and developers to consider a simpler 
certification process for civilian drone operators and to expand the allowable flight range beyond line-of-sight (Christie et al., 2016). Such new regulations would open the door for wider experimental application of drones and rigorous evaluation of their capacity to replace traditional aerial surveys. Research groups in Alaska, including the University of Alaska-Fairbanks and Exxon Mobil, are currently evaluating the use of drones in Arctic conditions for surveys of wildlife populations, hydrological and environmental conditions, and industrial equipment integrity (Exxon Mobil, 2017). If successful, drones could reduce reliance on low-flying aircraft for Arctic research.

Advancing research and regulation related to aircraftharvester interactions face several challenges, of which the most limiting are gaps in scientific knowledge and available data on aircraft-harvester interactions. Data are needed on harvester movement and patterns of avoidance. Social surveys that ask explicitly about harvester avoidance of aircraft (e.g., Stephen R. Braund \& Associates, 2017) could be combined with harvester GPS tracks from participatory research efforts to generate a spatial distribution of harvester activity and examine how harvest patterns are changing over time. Harvester data could then be integrated with annual monitoring of caribou movements among Arctic communities. Perhaps more pressing, any efforts to assess the extent of the conflict will be thwarted by an absence of accessible data on where and when aircraft are flying over traditional harvest areas. Researchers need to implement innovative methods to collect spatially and temporally explicit aircraft data in subsistence regions, and then make these data easily accessible to communities and decision makers. By doing so, stakeholders may be able to overcome the problem of agencies' differential jurisdiction over public lands and consequently diffuse databases on permitted aircraft activity.

\section{CONCLUSION}

Aircraft serve diverse purposes on Alaska's North Slope, some of which conflict with traditional harvest practices. Flights over traditional harvest areas during peak harvest seasons are reported to reduce harvest opportunities for rural communities that rely on caribou and other wildlife for economic and cultural wellbeing. Although aircraftharvester conflict has been documented extensively in public records, no peer-reviewed studies to date have examined the overlap among aircraft activity, traditional harvest patterns, and traditional resources such as caribou in Arctic Alaska. This knowledge gap obstructs our capacity to establish cause-and-effect relationships between aircraft and traditional harvest practices. Aircraft traffic is difficult to monitor, document, and regulate, particularly when it comprises such diverse users as it does across Alaska. Aircraft may be flying over traditional harvest areas during peak harvest seasons, but inconsistent requirements for permitted aircraft and inaccessible, diffuse records impede the dissemination of flight data and the engagement of local communities in management discourses (BLM SAP, 2012; Akpik-Lemen, 2015). Even if pilots were willing to consistently log their flight tracks, substantial human capital would be required for an entity (e.g., government agency, research group, or nongovernmental organization) to compile, organize, and distribute this information to interested parties or to manage an open-access database. Pilots are not at fault in this issue; it involves a multitude of players acting over an expansive region, each with behaviors that we expect to vary widely over space and time. All players involved are, to the best of our knowledge, following the current regulations, but those regulations appear inadequate to address the concerns of rural harvesters.

Improving communication and cooperation among aircraft users, local communities, and decision-makers will be the most immediate step toward balancing the priorities of diverse stakeholders and mitigating transient conflicts. Understanding how aircraft traffic impacts rural Arctic communities over the long term will require a coordinated and collaborative effort among institutions with multidisciplinary expertise. The spatial and temporal scales of published research are too narrow to disentangle the multifaceted interactions among aircraft, harvesters, and caribou and the inherent variability of these interactions. Experimental research at the scale needed to understand causal relationships would be extremely costly and likely considered personally invasive by both traditional harvesters and aircraft pilots. Future research efforts need to involve local people directly in the research process and produce informative tools that empower community leaders to engage in the management of their traditional lands and resources. Aircraft-harvester conflict is unlikely to subside without interdisciplinary and community-driven research that seeks to quantify harvester responses to aircraft and how aircraft affects harvest success.

To measure the realized impact of industrial expansion around rural Arctic communities, our research community needs to devote more attention to the sociocultural impacts of aircraft activity. The solution to aircraft-harvester conflict will not be simple, but studies that integrate social and ecological data could elucidate how aircraft, harvesters, and wildlife interact in real time and provide insight into the causal relationships within this socialecological system. Addressing this longstanding issue carries importance for managers who aim to balance the needs of diverse aircraft operators with the rights of public land users and subsistence harvesters, for researchers who need to access remote field sites while maintaining respectful relations with local communities, and for Indigenous people who depend on the traditional harvest of wildlife for their physical and cultural wellbeing. Studying aircraft-harvester conflict with an integrated, whole-system approach could not only increase awareness of how human activities impact rural and Indigenous communities, but also facilitate a review of regulatory structures and inform more collaborative mitigation discourses. 


\section{ACKNOWLEDGEMENTS}

This article benefitted substantially from the insightful comments and pointed criticisms of our reviewers. We would like to thank the community of Nuiqsut, Kuukpik Subsistence Oversight Panel, Inc., and many local hunters for collaborating with us and kindly sharing their time and knowledge. Funding for our research was provided by Alaska EPSCoR NSF Award \#OIA1208927 and the state of Alaska. We received additional financial and logistical support from the Institute of Arctic Biology and the Resilience and Adaptation Program at the University of Alaska Fairbanks, and the Bureau of Land Management Arctic Field Office. The findings and conclusions in this article reflect those of the authors and do not necessarily represent the views of the Bureau of Land Management.

\section{APPENDIX 1}

The following table is available in a supplementary file to the online version of this article at:

https://journalhosting.ucalgary.ca/index.php/arctic/rt/ suppFiles/68228/0

TABLE S1. Results from a systematic search of Google Scholar for literature on aircraft disturbance to humans and wildlife.

\section{REFERENCES}

Ahtuangaruak, R. 2015. Broken promises: The future of Arctic development and elevating the voices of those most affected by it - Alaska Natives. Politics, Groups, and Identities 3(4):673-677. https://doi.org/10.1080/21565503.2015.1080618

Akpik-Lemen, C. 2015. U.S. Department of the Interior Bureau of Land Management NPR-A Subsistence Advisory Panel meeting proceedings. Meeting held September $2 \& 3$ in Barrow, Alaska. Minutes on file at Arctic District Office, Bureau of Land Management, 222 University Ave., Fairbanks, Alaska 99709.

Alaska Board of Game. 2016. Findings related to Proposal 207: Restrictions on the use of aircraft associated with sheep hunting. Decision 2016-213-BOG.

http://www.adfg.alaska.gov/static/regulations/regprocess/ gameboard/pdfs/findings/16213.pdf

Alaska Federation of Natives. 2012. First Peoples of Alaska: Proclamation to achieve subsistence rights and protection of Native cultures. Available at 3000 A Street, Suite 210, Anchorage, Alaska 99503.

Anderson, B.A. 2007. A literature review of the effects of helicopter disturbance and noise on selected wildlife species. Prepared for U.S. Army Alaska and CH2M Hill Inc. Fairbanks, Alaska: ABR, Inc.-Environmental Research \& Services. http://catalog.northslopescience.org/catalog/entries/8591
Bacon, J.J., Hepa, T.R., Brower, H.K., Jr., Pederson, M., Olemaun, T.P., George, J.C., and Corrigan, B.G. 2011. Estimates of subsistence harvest for villages on the North Slope of Alaska, 1994-2003. Barrow: North Slope Borough Department of Wildlife Management.

Bélisle, A.C., Asselin, H., LeBlanc, P., and Gauthier, S. 2018. Local knowledge in ecological modeling. Ecology and Society 23(2): 14. https://doi.org/10.5751/ES-09949-230214

Bell, P.A, Mace, B.L., and Benfield, J.A. 2010. Aircraft overflights at national parks: Conflict and its potential resolution. U.S. Department of the Interior National Park Service. Park Science 26(3):65-67.

https://irma.nps.gov/DataStore/Reference/Profile/2201574

Bergerud, A.T. 1996. Evolving perspectives on caribou population dynamics, have we got it right yet? Rangifer 16(Special Issue 9):95-116. https://doi.org/10.7557/2.16.4.1225

Berkes, F. 2012. Sacred ecology: Traditional ecological knowledge and resource management, $3^{\text {rd }}$ ed. Philadelphia: Taylor \& Francis. https://doi.org/10.4324/9780203123843

Berkes F., Kislalioglu-Berkes, M., and Fast, H. 2007. Collaborative integrated management in Canada's North: The role of local and traditional knowledge and community-based monitoring. Coastal Management 35(1):143 - 162. https://doi.org/10.1080/08920750600970487

BLM (U.S. Department of the Interior, Bureau of Land Management). 1997. Official Transcript, Proceedings of Public Hearing for the NPR-A Integrated Activity Plan/ Environmental Impact Statement Scoping Meeting held April 10 in Nuiqsut, Alaska. Available at the BLM Arctic District Office, 222 University Avenue, Fairbanks, Alaska 99709.

- 2003. Alpine Satellite Development Plan Scoping Meeting. Meeting held March 18 in Nuiqsut, Alaska. Anchorage: Liz D'Amour and Associates. Available at the BLM Arctic District Office, 222 University Avenue, Fairbanks, Alaska 99709.

_. 2014. Greater Mooses Tooth Unit 1 Supplemental Environmental Impact Statement Public Participation/ ANILCA $§ 810$ Hearing Nuiqsut, Alaska. 13 March 2014, Nuiqsut, Alaska.

https://eplanning.blm.gov/epl-front-office/projects/ nepa/37035/47802/53749/GMT1_Nuiqsut_FINAL.pdf

- 2015. Supplemental Environmental Impact Statement for the Alpine Satellite Development Plan for the Proposed Greater Mooses Tooth One Development Project. Record of Decision. https://eplanning.blm.gov/epl-front-office/projects/ nepa/37035/54639/59351/MASTER_GMT1ROD.Ver17 signed_2.13.15.pdf

. 2016. Meeting Proceedings (Public Comments). Greater Mooses' Tooth 2 SEIS Public Scoping Meeting \#1. 22 August 2016, Nuiqsut, Alaska.

https:/eplanning.blm.gov/epl-front-office/projects/nepa/6581 7/89370/106877/2016_8_22_NUI_GMT2_scoping_meeting_ transcript.pdf 
2017. BLM aviation rules and actions to reduce disturbance. Fairbanks: U.S. Department of the Interior, Bureau of Land Management Arctic Office.

https://blm-prod.opengov.ibmcloud.com/sites/blm.gov/files/ GetInvolved_Alaska_NPR-A_SAP_BLM_Aviation_Rules and_Actions_to_Reduce_Disturbance.pdf

BLM SAP (U.S. Department of the Interior, Bureau of Land Management NPR-A Subsistence Advisory Panel). 2010. NPR-A Subsistence Advisory Panel Meeting Proceedings. Meeting held December 16 in Barrow, Alaska. Minutes on file at Arctic District Office, Bureau of Land Management, 222 University Ave., Fairbanks, Alaska 99709.

2012. NPR-A Subsistence Advisory Panel Meeting Proceedings. Meeting held March 2 \& 3 in Barrow, Alaska. Minutes on file at Arctic District Office, Bureau of Land Management, 222 University Ave., Fairbanks, Alaska 99709.

- 2013. Final NPR-A Subsistence Advisory Panel Meeting Proceedings. Meeting held September 18 \& 19, 2013, Wainwright, Alaska. Transcript on file at the Arctic District Office, Bureau of Land Management, 222 University Ave., Fairbanks, Alaska 99709.

—. 2014. NPR-A Subsistence Advisory Panel Meeting Proceedings. Meeting held February 19 \& 20, 2014 in Fairbanks, Alaska. Minutes on file at Arctic District Office, Bureau of Land Management, 222 University Ave., Fairbanks, Alaska 99709.

2016. NPR-A Subsistence Advisory Panel Meeting Proceedings. Meeting held January 20 \& 21, 2016 in Anaktuvuk Pass, Alaska. Minutes on file at Arctic District Office, Bureau of Land Management, 222 University Ave., Fairbanks, Alaska 99709.

Bowles, A.E. 1995. Responses of wildlife to noise. In: Knight, R.L., and Gutzwiller, K.J., eds. Wildlife and recreationists: Coexistence through management and research. Washington, D.C.: Island Press. 109-156.

Braem, N.M., Pedersen, S., Simon, J., Koster, D., Kaleak, T., Leavitt, P., Patkotak, J., and Neakok, P. 2011. Technical Paper No. 361. Fairbanks: Alaska Department of Fish and Game, Division of Subsistence.

http://www.adfg.alaska.gov/techpap/TP361.pdf

Brinkman, T., Maracle, K.B., Kelly, J., Vandyke, M., Firmin, A., and Springsteen, A. 2014. Impact of fuel costs on high-latitude subsistence activities. Ecology and Society 19(4): 18. https://doi.org/10.5751/ES-06861-190418

Brook, R.K., and McLachlan, S.M. 2008. Trends and prospects for local knowledge in ecological and conservation research and monitoring. Biodiversity and Conservation 17(14):3501 - 3512 . https://doi.org/10.1007/s10531-008-9445-x

Brower, A. 2003. U.S. Department of the Interior Bureau of Land Management NPR-A Subsistence Advisory Panel Meeting Proceedings. Meeting held February 26 in Barrow, Alaska. Minutes on file at Arctic District Office, Bureau of Land Management, 222 University Ave., Fairbanks, Alaska 99709.
Brower, H.K., Jr., and Hepa, R.T. 1998. North Slope Borough Subsistence Harvest Documentation Project: Data for Nuiqsut, Alaska for the period July 1, 1994, to June 30, 1995. Barrow, Alaska: Department of Wildlife Management, North Slope Borough.

http://www.north-slope.org/assets/images/uploads/ Subsistence\%20Harvest\%20Doc\%20Report_Nuiqsut_94-95. pdf

Brower, W.C. 1980. Ethnic identity and revitalization: Psychocultural adaptation among the Eskimo of North Alaska. Unpubl. dissertation, University of Colorado at Boulder, Boulder, Colorado.

Brown, C.L., Braem, N.M., Kostick, M.L., Trainor, A., Slayton, L.J., Runfola, D.M., Mikow, E.H., et al. 2016. Harvests and uses of wild resources in 4 Interior Alaska communities and 3 Arctic Alaska communities, 2014. Technical Paper No. 426. Fairbanks: Alaska Department of Fish and Game, Division of Subsistence.

https://www.arlis.org/docs/vol1/M/972886420.pdf

Brown, W.E. 1979. Nuiqsut heritage: A cultural plan. Prepared for the Village of Nuiqsut and the North Slope Borough Planning Commission and Commission on History and Culture. Anchorage: Arctic Environmental Information and Data Center, Environment and Natural Resources Institute, University of Alaska.

https://www.blm.gov/sites/blm.gov/files/Planning_Alaska Nuiqsut_Paisangich_Heritage_Cultural_Plan.pdf

Brubaker, M., Bell, J., Dingman, H., Evans, S., Kasak, K., Itta, M., and Drake, R. 2014. Climate change in Nuiqsut, Alaska: Strategies for community health. Anchorage: Center for Climate and Health, Alaska Native Tribal Health Consortium. http://www.anthc.org/chs/ces/climate/climateandhealth reports.cfm

BurnSilver, S.B., Boone, R.B., Kofinas, G.P., and Brinkman, T.J. 2017. Modeling tradeoffs in a rural mixed economy: Hunting, working, and sharing in the face of economic and ecological change. In: Hegmon, M., ed. The give and take of sustainability: Archaeological and anthropological perspectives on tradeoffs. Cambridge: Cambridge University Press. 52-83.

Calef, G.W., DeBock, E.A., and Lortie, G.M. 1976. The reaction of barren ground caribou to aircraft. Arctic 29(4):201-212. https://doi.org/10.14430/arctic2805

Cameron, R.D., Smith, W.T., White, R.G., and Griffith, B. 2005. Central Arctic caribou and petroleum development: Distributional, nutritional, and reproductive implications. Arctic 58(1):1 -9. https://doi.org/10.14430/arctic382

Carr, K., Natcher, D.C., and Olfert, R. 2013. Measuring the economic impact of publicly funded research in northern Canada. Polar Geography 36(4):291 - 304. https://doi.org/10.1080/1088937X.2013.826746

Carroll, G.M., Parrett, L.S., George, J.C., and Yokel, D.A. 2005. Calving distribution of the Teshekpuk caribou herd, 1994-2003. Rangifer 25(Special Issue 16):27-35.

https://doi.org/10.7557/2.25.4.1767 
Christie, K.S., Gilbert, S.L., Brown, C.L., Hatfield, M., and Hanson, L. 2016. Unmanned aircraft systems in wildlife research: Current and future applications of a transformative technology. Frontiers in Ecology and the Environment 14(5):241-251. https://doi.org/10.1002/fee.1281

Cuomo, C.J., Eisner, W., and Hinkel, K. 2008. Environmental change, Indigenous knowledge, and subsistence on Alaska's North Slope. The Scholar and Feminist Online 7.1.

Davis, J.L. 1980. Status of Rangifer in the USA. In: Reimers, E., Gaare, E., and Skjenneberg, S., eds. Proceedings of the Second International Reindeer/Caribou Symposium, 17-21 September 1979, Røros, Norway. 793-797.

Exxon Mobil. 2017. Community ice cellar and environmental initiatives on Alaska's North Slope. Presentation by E. Febbo at the 2017 Arctic Energy Summit, 18-20 September 2017, Helsinki, Finland. Anchorage, Alaska: Institute of the North. http://arcticenergysummit.com/files/febbo-20170928031337. pdf

Fall, J.A. 2016. Regional patterns of fish and wildlife harvests in contemporary Alaska. Arctic 69(1):47-64. https://doi.org/10.14430/arctic4547

Firn, J., Ladouceur, E., and Dorrough, J. Integrating local knowledge and research to refine the management of an invasive non-native grass in critically endangered grassy woodlands. Journal of Applied Ecology 55(1):321 - 330. https://doi.org/10.1111/1365-2664.12928

Fix, P.J., and Ackerman, A. 2015. Noatak National Preserve sport hunter survey: Caribou hunters from 2010-2013. Natural Resource Report NPS/NOAT/NRR-2015/1005. Fort Collins, Colorado: National Park Service.

Fullman, T.J., Joly, K., and Ackerman, A. 2017. Effects of environmental features and sport hunting on caribou migration in northwestern Alaska. Movement Ecology 5: 4. https://doi.org/10.1186/s40462-017-0095-z

Galginaitis, M., and Petterson, J.S. 1990. Subsistence resource harvest patterns: Nuiqsut. Special Report No. 8, Contract No. 14-35-0004-60146, OCS Study MMS 90-0038. Prepared for U.S. Department of the Interior, Minerals Management Service, Alaska Outer Continental Shelf Region. La Jolla, California: Impact Assessment, Inc.

https://www.boem.gov/BOEM-Newsroom/Library/ Publications/1990/90_0038.aspx

Geist, V. 1971. Is big game harassment harmful? Oilweek 22:12 - 13. Calgary, Alberta.

Georgette, S., and Loon, H. 1988. The Noatak River: Fall caribou hunting and airplane use. Technical Paper No. 162. Kotzebue: Alaska Department of Fish and Game, Division of Subsistence. http://www.subsistence.adfg.state.ak.us/techpap/tp162.pdf

Halas, G. 2015. Caribou migration, subsistence hunting, and user group conflicts in northwest Alaska: A traditional knowledge perspective. MSc thesis, University of Alaska Fairbanks. http://hdl.handle.net/11122/6090
Hansen, W.D., Brinkman, T.J., Leonawicz, M., Chapin, F.S., III, and Kofinas, G.P. 2013. Changing daily wind speeds on Alaska's North Slope: Implications for rural hunting opportunities. Arctic 66(4):448-458.

https://doi.org/10.14430/arctic4331

Harrington, F.H., and Veitch, A.M. 1991. Short-term impacts of low-level jet fighter training on caribou in Labrador. Arctic 44(4):318-327. https://doi.org/10.14430/arctic1554

Hatfield, J., Job, R.F.S., Hede, A.J., Carter, N.L., Peploe, P., Taylor, R., and Morrell, S. 2002. Human response to environmental noise: The role of perceived control. International Journal of Behavioral Medicine 9(4):341 - 359. https://doi.org/10.1207/S15327558IJBM0904_04

Heberlein, T.A. 2002. Peer-reviewed articles too many hunters or not enough deer? Human and biological determinants of hunter satisfaction and quality. Human Dimensions of Wildlife 7(4):229-250. https://doi.org/10.1080/10871200214753

Huntington, H.P., Gearheard, S., Mahoney, A.R., and Salomon, A.K. 2011. Integrating traditional and scientific knowledge through collaborative natural science field research: Identifying elements for success. Arctic 64(4):437-445.

https://doi.org/10.14430/arctic4143

ICAS (Iñupiat Community of the Arctic Slope). 2014. Resolution 2014-12: Resolution addressing the inalienable nature of Inupiat subsistence/harvest rights within the Arctic Slope. Barrow, Alaska. In: Appendix K: (Chapter 4 Section 4.5: Subsistence). Greater Mooses Tooth 2 Development Project Draft Supplemental Environmental Impact Statement. https://eplanning.blm.gov/epl-front-office/projects/ nepa/65817/127983/155730/Appendix_K-_North_Slope_ Aviation_Disturbance_Information.pdf

Klein, D.R. 1991a. Caribou in the changing North. Applied Animal Behaviour Science 29(1-4):279-291.

. 1991b. Limiting factors in caribou population ecology. Rangifer 11(Special Issue 7):30-35.

https://doi.org/10.7557/2.11.4.990

Kruse, J.A, Kleinfeld, J., and Travis, R. 1982. Energy development effects on Alaska's North Slope: Inupiat population. Human Organization 41(2):97-106.

https://oi.org/10.17730/humo.41.2.t823308164w76158

Kunaknana, S. 2016. Final Greater Mooses Tooth 1 Compensatory Mitigation Funds Planning Meeting Proceedings. Meeting held April 22 in Nuiqsut, Alaska. Minutes on file at Arctic District Office, Bureau of Land Management, 222 University Ave., Fairbanks, Alaska 99709.

Lambden, J., Receveur, O., and Kuhnlein, H.V. 2007. Traditional food attributes must be included in studies of food security in the Canadian Arctic. International Journal of Circumpolar Health 66(4):308-319. https://doi.org/10.3402/ijch.v66i4.18272

Legal Information Institute. 2018. Code of Federal Regulations Title 14 Chapter 1 - Federal Aviation Administration, Department of Transportation. Online database. Ithaca, New York: Cornell Law School. https://www.law.cornell.edu/cfr/text/14/chapter-I 
Loring, P.A., and Gerlach, S.C. 2015. Searching for progress on food security in the North American North: A research synthesis and meta-analysis of the peer-reviewed literature. Arctic 68(3):380-392.

https://doi.org/10.14430/arctic4509

Mace, B.L., Bell, P.A., and Loomis, R.J. 1999. Aesthetic, affective, and cognitive effects of noise on natural landscape assessment. Society \& Natural Resources 12(3):225-242. https://doi.org/10.1080/089419299279713

Magdanz, J.S., Utermohle, C.J., and Wolfe, R.J. 2002. The production and distribution of wild food in Wales and Deering, Alaska. Technical Paper No. 259. Juneau: Alaska Department of Fish and Game, Division of Subsistence.

Magdanz, J.S., Greenberg, J., Little, J., and Koster, D.S. 2016. The persistence of subsistence: Wild food harvests in rural Alaska, 1983-2013. SSRN (May 13, 2016).

https://doi.org/10.2139/ssrn.2779464

Mahoney, S.P., and Schaefer, J.A. 2002. Hydroelectric development and the disruption of migration in caribou. Biological Conservation 107(2):147-153. https://doi.10.1016/s0006-3207(02)00052-6

Maier, J.A.K., Murphy, S.M., White, R.G., and Smith, M.D. 1998. Responses of caribou to overflights by low-altitude jet aircraft. The Journal of Wildlife Management 62(2):752-766. https://doi.org/10.2307/3802352

McClure, C.J.W., Ware, H.E., Carlisle, J., Kaltenecker, G., and Barber, J.R. 2013. An experimental investigation into the effects of traffic noise on distributions of birds: Avoiding the phantom road. Proceedings of the Royal Society B 280(1773): 20162290.

https://doi.org/10.1098/rspb.2013.2290

McCourt, K.H., Feist, J.D., Doll, D., and Russell, J.J. 1974. Disturbance studies of caribou and other mammals in the Yukon and Alaska, 1972. Arctic Gas Biological Report Series: Vol. 5. Anchorage, Alaska: Renewable Resources Consulting Services Ltd.

Moller, H., Berkes, F., O’Brian Lyver, P., and Kislalioglu, M. 2004. Combining science and traditional ecological knowledge: Monitoring populations for co-management. Ecology and Society 9(3): 2 .

https://doi.org/10.5751/ES-00675-090302

Murphy, S.M., and Curatolo, J.A. 1987. Activity budgets and movement rates of caribou encountering pipelines, roads, and traffic in northern Alaska. Canadian Journal of Zoology 65(10):2483-2490.

https://doi.org/10.1139/z87-375

Murphy, S.M., and Lawhead, B.E. 2000. Caribou. In: Truett, J.C., and Johnson, S.R., eds. The natural history of an Arctic oil field: Development and biota. New York: Academic Press. 59-84.

https://doi.org/10.1016/B978-012701235-3/50006-4

Napageak, T., Sr. 2000. U.S. Department of the Interior Bureau of Land Management NPR-A Subsistence Advisory Panel Meeting Proceedings. Meeting held June 8, in Nuiqsut, Alaska. Minutes on file at Arctic District Office, Bureau of Land Management, 222 University Ave., Fairbanks, Alaska 99709.
Nowacki, G., Spencer, P., Brock, T., Fleming, M., and Jorgenson, T. 2001. Ecoregions of Alaska and neighboring territory (map). Reston, Virginia: U.S. Geological Survey.

https://databasin.org/datasets/6a792aa584344d3ca98745b20 $1 \mathrm{~b} 64223$

NPR-A (National Petroleum Reserve in Alaska) Working Group. 2014. General principles for development of infrastructure in northern Alaska. Available at the Bureau of Land Management Arctic Office, 222 University Avenue, Fairbanks, Alaska 99709.

NRC (National Research Council). 2003. Cumulative environmental effects of oil and gas activities on Alaska's North Slope. Washington, D.C.: National Academies Press.

NSB (North Slope Borough). 2014. Oil and Gas Technical Report: Planning for oil \& gas activities in the National Petroleum Reserve-Alaska. Barrow: Department of Planning \& Community Services, North Slope Borough.

http://www.north-slope.org/departments/planningcommunity-services/oil-and-gas-technical-report

_ 2015. Draft Nuiqsut Comprehensive Development Plan. Prepared by Community Planning and Real Estate Division, Department of Planning \& Community Services, Nuiqsut, Alaska. Barrow: North Slope Borough.

http://www.northslope.org/assets/images/uploads/NUI Public_Review_Draft_Reduced_Size.pdf

2016. North Slope Borough 2016 Oil and Gas Forum: Promoting responsible development through better coordination. Summary report of a forum held 20-22 July 2016, Anchorage, Alaska. Barrow: North Slope Borough.

http://www.north-slope.org/assets/images/uploads/news/ FinalOGforumReport.pdf

NSSI [North Slope Science Initiative]. 2017. North Slope Science Initiative Science Technical Advisory Panel Meeting Summary and Minutes, 7-8 November 2017.

https://northslopescience.org/wp-content/uploads/171107 STAP_MeetingMinutes.pdf

Nuttall, M. 2000. Indigenous peoples, self-determination and the Arctic environment. In: Nuttall, M., and Callaghan, T.V., eds. The Arctic: Environment, people, policy, $1^{\text {st }}$ ed. Amsterdam: Overseas Publishers Association N.V. 377-409.

Nuttall, M., Berkes, F., Forbes, B., Kofinas, G., Vlassova, T., and Wenzel, G. 2005. Hunting, herding, fishing, and gathering: Indigenous peoples and renewable resource use in the Arctic. Chapter 12. Arctic Climate Impact Assessment: ACIA Overview report. 649-690.

https:/www.amap.no/documents/doc/arctic-arctic-climateimpact-assessment/796

Olsson, P., and Folke, C. 2001. Local ecological knowledge and institutional dynamics for ecosystem management: A study of Lake Racken watershed, Sweden. Ecosystems 4(2):85 - 104. https://doi.org/10.1007/s100210000061

Osipov, I.A., Aksnes, D.W., Kullerud, L., Radford, G., Hirshberg, D., Christian, K., Adie, E., Liu, J., and Sorensen, A.A. 2016. Arctic altmetrics: Alternative perspectives on the impact of Arctic research. A Working Paper. Posted on 14 September 2016. Figshare.

https://doi.org/10.6084/m9.figshare.3811233.v1 
Padilla, E., and Kofinas, G.P. 2014. "Letting the leaders pass": Barriers to using traditional ecological knowledge in comanagement as the basis of formal hunting regulations. Ecology and Society 19(2): 7. https://doi.org/10.5751/ES-05999-190207

Parlee, B.L., Goddard, E., Łutsël K'é Dene First Nation, and Smith, M. 2014. Tracking change: Traditional knowledge and monitoring of wildlife health in northern Canada. Human Dimensions of Wildlife 19(1):47-61. https://doi.org/10.1080/10871209.2013.825823

Polfus, J.L., Manseau, M., Simmons, D., Neyelle, M., Bayha, W., Andrew, F., Andrew, L., Klütsch, C.F.C., Rice, K., and Wilson, P. 2016. Łeghagots'enete (learning together): The importance of Indigenous perspectives in the identification of biological variation. Ecology and Society 21(2): 18. https://doi.org/10.5751/ES-08284-210218

Prichard, A.K., and Murphy, S.M. 2004. Analysis and mapping of satellite telemetry data for the Teshekpuk caribou herd, 1990-2002. Final Report prepared for the North Slope Borough, Barrow. Fairbanks: ABR, Inc.

Reimers, E., and Colman, J.E. 2006. Reindeer and caribou (Rangifer tarandus) response towards human activities. Rangifer 26(2):55-71. https://doi.org/10.7557/2.26.2.188

Silvano, R.A.M, and Valbo-Jørgensen, J. 2008. Beyond fishermen's tales: Contributions of fishers' local ecological knowledge to fish ecology and fisheries management. Environment, Development and Sustainability 10:657-675.

https://doi.org/10.1007/s10668-008-9149-0

Skoog, R.O. 1968. Ecology of the caribou (Rangifer tarandus granti) in Alaska. PhD thesis, University of California Berkeley, Berkeley, California.

Smith, J., Saylor, B., Easton, P., Wiedman, D., and Elders from the Alaska Villages of Buckland and Deering. 2009. Measurable benefits of traditional food customs in the lives of rural and urban Alaska Iñupiaq elders. Alaska Journal of Anthropology 7(1):89-99.

Steinacher, S. 2006. A crisis in the making in Northwest Alaska: Caribou, hunting pressure and conflicting values. Alaska Fish \& Wildlife News, September 2006. Juneau: Alaska Department of Fish and Game.

http://www.adfg.alaska.gov/index.cfm?adfg=wildlifenews. view_article\&articles_id $=236$

Stephen R. Braund \& Associates. 2009. Impacts and benefits of oil and gas development to Barrow, Nuiqsut, Wainwright, and Atqasuk harvesters. Prepared for the North Slope Borough, Department of Wildlife Management. Anchorage: Stephen R. Braund \& Associates.

http://www.north-slope.org/assets/images/uploads/ Braund $\% 20$ NSB $\% 20$ Oil $\% 20$ and $\% 20$ Gas $\% 20$ Impacts $\% 20$ July\%2009.pdf

. 2013. Nuiqsut Caribou Subsistence Monitoring Project:

Results of year 4 hunter interviews and household harvest surveys. Prepared for ConocoPhillips Alaska, Inc. Anchorage: Stephen R. Braund \& Associates.

http://www.north-slope.org/assets/images/uploads/Nuiqsut_ Caribou_Monitoring_Y4_Report_July19.pdf
2014. Nuiqsut Caribou Subsistence Monitoring Project: Results of year 5 hunter interviews and household harvest surveys. Prepared for ConocoPhillips Alaska, Inc. Anchorage: Stephen R. Braund \& Associates.

- 2015. Nuiqsut Caribou Subsistence Monitoring Project: Results of year 6 hunter interviews and household harvest surveys. Prepared for ConocoPhillips Alaska, Inc. Anchorage: Stephen R. Braund \& Associates.

- 2016. Nuiqsut Caribou Subsistence Monitoring Project: Results of year 7 hunter interviews and household harvest surveys. Prepared for ConocoPhillips Alaska, Inc. Anchorage: Stephen R. Braund \& Associates.

- 2017. Nuiqsut Caribou Subsistence Monitoring Project: Results of year 8 hunter interviews and household harvest surveys. Prepared for ConocoPhillips Alaska, Inc. Anchorage: Stephen R. Braund \& Associates.

http://www.north-slope.org/assets/images/uploads/Nuiqsut Caribou_Monitoring_Y8_Report_Aug17.pdf

U.S. Army Corps of Engineers. 2016. Nanushuk Project Environmental Impact Statement. Appendix II: Scoping and Public Meetings.

ht t p://www.nanushukeis.com/documents / FEIS / Appendices/2\%20Appendix\%20II\%20Scoping_20181022.pdf

U.S. Army Engineer District, Alaska. 1996. Chapter 7.0 Affected human environment and impacts. Final Environmental Impact Statement for the Proposed Beaufort Sea Oil and Gas Development, Northstar EIS Project.

https://www.arlis.org/docs/vol2/point_thomson/1121/ VOLUME3/CHAPTER7/Chapter7.pdf

U.S. Department of the Interior. 2017. Federal Subsistence Board approves partial closure of Federal public lands to caribou hunting in Unit 23. Press release.

https://www.doi.gov/subsistence/news/general/federalsubsistence-board-approves-partial-closure-federal-publiclands

Valkenburg, P. 2001. Stumbling towards enlightenment: Understanding caribou dynamics. Alces 37(2):457-474.

Vaske, J.J., and Shelby, L.B. 2008. Crowding as a descriptive indicator and an evaluative standard: Results from 30 years of research. Leisure Sciences 30(2):111-126.

https://doi.org/10.1080/01490400701881341

Vistnes, I.I., and Nellemann, C. 2008. The matter of spatial and temporal scales: A review of reindeer and caribou response to human activity. Polar Biology 31:399-407. https://doi.org/10.1007/s00300-007-0377-9

Vistnes, I.I., Nellemann, C., Jordhøy, P., and Støen, O.G. 2008. Summer distribution of wild reindeer in relation to human activity and insect stress. Polar Biology 31:1307-1317. https://doi.org/10.1007/s00300-008-0468-2

WAH (Western Arctic Caribou Herd) Working Group. 2016. Final 2016 meeting summary, December 14-15, Anchorage, Alaska. https://westernarcticcaribounet.files.wordpress.com/ 2018/03/2016-wach-wg-meeting-summary-final-w-allattachments-1.pdf 
Watts, A.C., Petty, J.H., Smith, S.E., Burgess, M.A., Wilkinson, B.E., Szantoi, Z., Ifju, P.G., and Percival, H.F. 2010. Small unmanned aircraft systems for low-altitude aerial surveys. The Journal of Wildlife Management 74(7):1614-1619. https://doi.org/10.1111/j.1937-2817.2010.tb01292.x

Wilson, R.R., Prichard, A.K., Parrett, L.S., Person, B.T., Carroll, G.M., Smith, M.A., Rea, C.L., and Yokel, D.A. 2012. Summer resource selection and identification of important habitat prior to industrial development for the Teshekpuk caribou herd in northern Alaska. PLoS One 7(11): e48697.

https://doi.org/10.1371/journal.pone.0048697
Wolfe, R.J. 1984. Local traditions and subsistence: A synopsis from twenty-five years of research by the state of Alaska. Technical Paper No. 284. Juneau: Alaska Department of Fish and Game, Division of Subsistence.

2013. Sensitive tribal areas on the Arctic Slope: An update of areas, issues, and actions in four communities. Prepared for the Inupiat Community of the Arctic Slope, Barrow, Alaska. http://www.inupiatgov.com/files/North $\% 20$ Slope $\% 20$ Sensitive\%20Tribal\%20Areas\%20Final\%20Report.pdf

Wolfe, R.J., Scott, C.L., Simeone, W.E., Utermohle, C.J., and Pete, M.C. 2009. The "super-household." In: Alaska Native subsistence economies. Final Report to National Science Foundation Project ARC 352611. Anchorage: Alaska Department of Fish and Game. 